\title{
Internet Financial Reporting in Malaysia: The Preparers’ View
}

DR KIEW-HEONG YAP (Corresponding author)

Faculty of Business and Accountancy

University of Malaya, 50603 Kuala Lumpur

Tel: 60-1-6371-7660,60-3-6250-1367Ｅ-mail: ayapkh@gmail.com

DR ZAKIAH SALEH

Faculty of Business and Accountancy

University of Malaya, 50603 Kuala Lumpur

E-mail: szakiah@gmail.com

Received: November 8, 2011 Accepted: November 18, 2011 Published: December 1, 2011

doi:10.5296/ajfa.v3i1.1067 URL: http://dx.doi.org/10.5296/ajfa.v3i1.1067

\begin{abstract}
This paper reports the opinion and awareness of the Internet financial reporting (IFR) from the preparers' perspectives and examines the individual firm motives to engage the IFR. The researchers interviewed ten senior managers using semi-structured and in-depth questionnaires to seek their views and opinions on IFR issues. Among the three main motivations to engage in IFR are: first, companies want to be more transparent in disseminating company information. Second, the companies use the Internet to promote their products and services to create a good brand name in the industry. Lastly, these companies are a strong believer of good corporate governance best practices in promoting greater transparency. $90 \%$ of the respondents claimed ownership structure influenced IFR, and 70\% of the respondents agreed industry members and firm size influenced such reporting practice. As for corporate governance mechanisms, only $34 \%$ of the respondents agreed corporate governance influenced IFR. This paper bridges the gap by interviewing preparers concerning influences of corporate governance and ownership structures on IFR. Among the more significant issues highlighted by the respondents are the security of the Web site, timeliness of reporting and adoption of XBRL.
\end{abstract}

Keywords: Internet financial reporting, Preparers’ views 


\section{Introduction}

Internet is becoming a popular mean of communication with all stakeholders. Many corporations in developed and developing economies have a dedicated Web site to communicate financial information with the investors. This reporting practice is called Internet financial reporting (IFR). IFR can be defined as 'the public reporting of operating and financial data by a business enterprise by the World Wide Web or related Internet-based communications medium” (Lymer et al., 1999, p.2). Internet reporting activities are largely driven by preparers who use it to market their products or services. Reporting companies may be motivated by the benefits of communicating information by the Internet. These benefits included: providing companies for global marketing, decreasing the distribution cost of hard copy financial statements, communicating information cheaper, wider and faster; and facilitating interaction with stakeholders (Xiao et al., 2002).

There have been much empirical work carried out for IFR by the practitioners and academicians from the developed economies, however, only limited studies have offered some reasons about the relationship between the opinion, motivation and influences of IFR, especially for Malaysia. Past Malaysian studies were mainly descriptive in nature (Nik Salleh and Mohamad, 2000; Jamaliah et al., 2001; Mohamad et al., 2003), and examined few factors that influenced the IFR (Hassan et al., 1999; Ismail and Tayib, 2000; Gan and Susela, 2002; Abdul Hamid et al., 2004). The study on the perception of preparers was solicited by mailed questionnaire (Hassan et al., 1999; Ali Khan and Ismail, 2009). This paper argues further research could try other approaches, such as in-depth interviewing with the preparers. According to Saunders et al. (2009), semi-structured and in-depth interviews provide an opportunity to the researchers to 'probe' answers, where he/she wants an explanation from interviews to build on their responses. Interviewees may use ideas or words in a specific way, and probing of these meanings will add depth and significance to the data collected. They may also lead the discussion into areas that are important for understanding and had not been previously considered by the researchers. Therefore, this study tries to bridge the gap by interviewing ten senior managers to seek their views and opinions on influences of corporate governance and ownership structures on IFR. This paper reports the opinion and awareness of the IFR from the preparers' perspectives and examines the individual firm motives. Views on the influences of corporate governance mechanisms and ownership structures are sought and the disclosure theories are used in the data interpretation process. IFR issues highlighted by the respondents are presented.

The remainder of this paper is organised as follows. Section 2 reviews the prior interviews studies of IFR. Section 3 outlines the research method. Section 4 discusses the result of the in-depth semi-structure interview with the respondents. This section is divided into 3 sub-sections - Section 4.1 presents the opinion and awareness of the managers; and Section 4.2 discusses the individual firm motives. The interview data obtained from each respondent are analysed to find out the themes and summarised into tables. Views on the influences of corporate governance mechanisms and ownership structures are presented in Section 4.3. The disclosure theories are used in the data interpretation process (Section 4.4). Lastly, IFR issues highlighted by the respondents are discussed in Section 4.5. Finally, the results are concluded 
in Section 5.

\section{Literature Review}

\subsection{Interviews}

Studies on the views of interested parties on IFR started since 1999. The Internet has been described as "a new platform for distributing financial information” (Hassan et al., 1999, p.1). It is a platform that shows distinctive and attractive features, which makes it an effective choice when compared with the traditional platform. Hassan et al. (1999) studied the opinions of Malaysian chief financial officers (CFO) on the usefulness, benefits and costs of the Internet disclosure and reporting of financial information. They used a mailed questionnaire to seek the opinions of the controllers, which achieved a response rate of $35.04 \%$. The findings suggest the benefits, to both the companies and the users of financial information, are perceived to be greater than the costs of adopting the Internet as another medium of communicating and disclosing corporate financial information.

Increasingly, companies are using the Internet to present financial information. However, there is little published literature on the extent of this new medium that is shaping the future of corporate reporting practices (Xiao et al., 2002). To widen the participation in the debate, they propose the non-technological and technological factors will decide the future of IFR; there is a range of different views in other areas obtained from 17 U.K. experts including regulators, auditors, academics, reporting companies and users of corporate reports. Some opinions are non-technologically driven such as resistance to changes in technology, regulators are slow to react and users are not interested in reading financial reports, whereas, others pay more attention to technology factors. Some experts adopt a more progressive or even radical perspective, while others do not foresee any financial reporting changes within the short period of time. The experts did not address some important issues such as the relative importance of the identified contingency factors that will affect the changes related to Internet; the state of these factors will take effect, and the integration impact of Internet with data processing systems.

A study by Beattie and Pratt (2003) reports the findings of a U.K. study about the views of 500 individuals from preparers, various user groups and auditors on newly emerging practices and specific change proposals. They found users like the scope expanded by the Web. All groups found the range of navigation aids; search aids and file formats were least useful. File format preferences vary across the groups. Paired group comparison shows the views of the preparers and users differ substantially, while expert and non-expert users hold the same views on many issues. Generally, auditors' views fall between the views of preparers and users. This study has three specific limitations. First, the extent to which members of ProShare and UKSA representing the private shareholders population is unknown. Second, it is unclear how or why industry membership might influence the views of financial company finance directors, because these views were not sampled. Third, this study considered the U.K. settings and participants only. 
Jones and Xiao (2004) report the results of a Delphi study into corporate financial reporting by 2010, in which 20 U.K. experts in accounting and the Internet, representing regulators, auditors, academics, reporting companies and users, took part in the study. They conclude the financial reporting package would change into "a core of general-purpose, standardised information (in both the hard copy and Internet version) with a non-core general purpose and customised information” (Jones and Xiao, 2004, p.1). Prior studies suggested radical changes such as raw data disclosure and real-time reporting would not occur, at least to the core package. Regulators will adopt a minimalist approach while auditors will be cautious and reactive. Standardisation and customisation will be the fundamental dilemma of Internet financial reporting in the future.

Most recent study by Ali Khan and Ismail (2009) examined the factors that influence Malaysian companies to engage in IFR. This paper sought the opinions of preparers of financial information by a mailed questionnaire. The findings suggest three factors that firms perceive as important: (1) enhance corporate image, (2) company teller with the technology development, and (3) competitors in the industry. However, 'the need to keep information updated', 'required expertise from the company' and 'concern over security of information' are the three main factors that inhibit companies from adopting IFR the most. The researchers suggest further studies could try other approaches, such as interviewing companies and preparers to gain an in-depth understanding about the factors influencing Malaysian companies to engage in IFR.

\subsection{Determinants of IFR}

Many researchers conducted empirical studies to identify factors associated with IFR, firm-specific determinants include industry type, firm size and profitability (Debreceny et al., 2002; Ettredge et al., 2002; Marston and Polei, 2004; Debreceny and Rahman, 2005; Bonson and Escobar, 2006). It can be concluded certain specific firm characteristics such as firm size appear to be statistically associated with the extent of IFR.

Xiao et al. (2004) argue IFR is responsive to specific environment attributes. This study found state share ownership is negatively related to IFR, legal person ownership is positively associated with IFR. The negative relationship proves the state owners have privileged access to private information, whereas the legal person shareholders have motivation to oversee company management. The authors argue important determinants of disclosure choice in the developed economies may not apply to Chinese environment.

Abdelsalam et at. (2007) found analyst following, director ownership, director independence and CEO duality is related to IFR. However, the results of the random sample of 110 top quartile listed companies may not generalise to smaller listed companies on the exchange.

More recent IFR study link IFR to corporate governance mechanisms. The findings by Kelton and Yang (2008) show U.S. firms with weak shareholder rights, a low percentage of block holder ownership, a higher percentage of independent directors, a more diligent audit committee and a higher percentage of audit committee members with financial expertise are more likely to have IFR. The findings may not generalise to listed companies from other 
stock exchanges. Future study may examine other characteristics such as reporting frequency and information quality.

Prior interview studies mainly focused on issues related to IFR; whereas determinant studies examined the relationships between various factors to its influence on IFR. This paper tries to link the IFR practices to its determinants by examining from the preparers' views about the influences of corporate governance mechanisms and ownership structures on IFR. This study uses the disclosure theories to interpret the results, because it improves our understanding on IFR practices.

\section{Research Method}

Many researchers put much effort examining the initial financial disclosure, and studying the managements' decisions in voluntarily non-obligatory disclosure. However, there are limited empirical findings available about what drives the companies to incur extra distribution costs related to Internet reporting. Currently, limited empirical evidence about Internet disclosure is available in the Malaysian accounting literature; however, the Internet's potential role for communicating company information has been debated more in advanced countries such as the U.K. and U.S. This study extends prior studies by interviewing the preparers of Malaysian listed companies about their views and opinions, specifically on the influences of corporate governance and ownership structures on IFR practices.

The interview questions are divided in two categories: the first category included five open-ended questions dealing with opinion, needed financial information, reporting format and other issues about IFR. The questions began with a short paragraph providing a definition of Internet reporting. The second category included eight theme-guided questions dealing with Internet regulation, influences of IFR from various parties or sources such as industry members, firm's size, financial performance (profitability), beta (systematic risk), auditor type, ownership structure and board governance structures. It was also made clear these questions are only related to the IFR of the sample companies.

The researchers' pilot tested the questionnaire using four individuals (two audit partners; one regulator and one academician) and changed the content accordingly. The researchers emailed the questionnaires to the investor relations department of the sample companies, with an explanatory letter giving the background to the study and an assurance of confidentiality of responses. The first mailing to all sample companies took place in May 2009.

\subsection{Sampling}

Sampling is important; as the researchers cannot possibly study everything everyone is doing everywhere. In qualitative research, Punch (2005) admits there are no summarised sampling strategies because of a great variety of purposes, approaches and settings for research. Huberman and Miles (2002) mentioned qualitative researchers usually studied small samples size, which are examined in depth and nested in their context, in contrast to quantitative researchers who aim for larger context numbers such as seeking statistical significance and stripped cases. Punch (2005) argues the basic ideas of specific sampling strategies change is to reflect the study's purposes and questions. He stresses the direction should be coherent and 
consistent with the study logic.

Purposive sampling is employed in this study to select the companies to be sampled. The sampling is confined to listed companies that disseminate information on their company web page. Selection of rich case information for an in-depth study influences the logic and power of purposive sampling (Patton, 2002). Information rich refers to those cases where the researchers can learn many centrally important issues for the research objective.

This study used two of the strategies under purposefully selecting information-rich cases (Patton, 2002) in deciding on the sample. First, is the intensity of sampling. This sampling strategy consists of information - rich cases that show the interested phenomenon intensely but not extremely (Patton, 2002). To discover the variation type under the investigated situation, exploratory work needs to be done under this sampling strategy.

Companies chosen to be the sample in this part of the study are the listed companies that report a significant amount of information on their company web page. This coincides with the strategy suggested above. As the purpose of the study is to identify what motivates the firms to engage in IFR, it seems proper to study only companies that are practising it. Reviewing their company homepage assesses this practice. To meet the intensity criteria stated by Patton (2002), this study finds the potential sampling through the list of companies that ranked the highest score under the corporate governance survey 2008, by their compliance with the corporate disclosure and governance. One of the key areas covered is shareholders and investor relations, which emphasised improving the accessibility and transparency of financial disclosures to investors.

The second strategy adopted is to use the maximum variation sampling (Patton, 2002). This aims at describing and capturing the main principles, outcomes or themes that affect most variation in participants (Patton, 2002). The objective in this study is to explain IFR phenomenon in Malaysia without any limit on the industry type. In the prior studies, the industry type is considered to be significant in influencing IFR. This study tries to see the various responses across the various industries for Malaysia.

\subsection{Data Collection}

The researchers used search engines, e.g. Yahoo and Google to find Web pages of the Top 120 sample companies that ranked the highest score under the corporate governance survey 2008, of which only 17 companies included the investor relations contact on the Internet. Reviews of the potential respondents were conducted prior to select the particular respondents. Then, the researchers made a telephone call to arrange an appointment with these investor relations' personnel. They confirmed the appointment after a few follow up calls; finally, the researchers interviewed senior managers from ten companies. Appendix 2 lists the details of the companies and the persons interviewed. In addition, company backgrounds by their Internet reporting were investigated. The information served to confirm the reliability of the interview responses and allowed more direct and detailed probing in the interviews.

The researchers used a standardised set of questions to interview the respondents. These 
questions served in extracting the required information from them. The purpose of using open-ended questions is to invite participation from the respondents during the conversation (Cooper and Schindler, 2006; Saunders et al., 2009). Since, all the respondents are high-ranking personnel with a busy schedule, time management is important. Only respondents who were seen to be more receptive were probed to get more in-depth responses. If time permitted respondents were asked concerning the aspects of the emerging theory. Every respondent was asked the same questions. Some respondents were asked further questions to gain more information. Appendix 1 sets out the list of questions asked during the interview sessions.

The researchers emailed a letter with a set of questionnaires with a standard definition of Internet reporting to the interviewees. During the interview, the researchers briefly explained the definition and the concept of Internet reporting to all the respondents, as some of them did not read the letter emailed to them earlier thoroughly. The main purpose of the interview was to identify what motivates them to disclose financial information by the Internet. The researchers began by asking the respondent's opinion before going to the main questions. Then, by asking a question that is broad in nature, the researchers can identify their real motivation. The main objective is to gain the information about their opinion and experience, followed by more specific questions.

English was the main language used during the interview. The researchers taped the conversation with respondents and transcribed literally to help data analysis. The researchers took note of the important points highlighted by the respondents during the interview. The overall duration of the interviews ranged between 30 and 60 minutes. The researchers interviewed all respondents during May 2009 to August 2009.

\subsection{Data Analysis Techniques}

The data transcription took a long time as the researchers listened to the tape several times to transcribe all the conversations properly. While listening to the tape, the researchers noted emerging or interesting points. This initial process helped the researchers to be more prepared to investigate the subsequent respondents. The emerging pattern was evident from the initial analysis.

The researchers began post interview analysis immediately after collecting data for each interview. For each respondent, the average total transcription was four to five pages of A4, single spaced and font 11 Arial characters. The researchers read each respondent transcript several times. The reading was done simultaneously with the transcription process to get the big picture.

The researchers identified the underlying themes based on the evidence collected from the transcribed data. Data reduction process continued by making summaries of the patterns emanating from the evidence. The following stage of the data analysis process was cross-analysing and comparing the coded summarised data with the respondents' profile, such as their stakeholders, nature of their business, their products or services offered.

The researchers referred to the interview guide and the research question simultaneously 
during the interpretation process to elaborate the findings according to the research questions. This study identified the perception of the local companies practising Internet reporting. Second, the influences of various factors on IFR were identified. Third, this study examined the applicability of disclosure theories to understand the companies' motivation and determinants of IFR.

The analysis focused on five aspects. First, the analysis identified opinions of the preparers. Second, it explored the motivations of engaging Internet reporting. Third, it identified the influences of firm characteristics, corporate governance mechanisms and ownership structures on IFR. Fourth, it discussed finding based on disclosure theories, namely agency theory and institutional theory. Finally, it discussed issues relating to IFR. Even though, the divided scope was clearly stated, the researchers are aware these aspects overlap in the sense that the first aspect of opinions cannot be simply ignored in considering the motivation, influence or in finding support for the disclosure theories. This strategy is meant to help the researchers in interpreting the findings. The first, second and third aspects were discussed in narration form. To explain the motivations and influences, tables (Table 1 to Table 4) were developed and examined to give detailed explanation. This fourth part was explained through the lens of disclosure theories.

\section{Results of Interview}

\subsection{Open Questions: Opinions on Internet Reporting}

This section is mainly narrative. It tries to get into the thoughts of the respondents, and to understand the real meaning of what they were trying to reveal. To make the discussion meaningful, the discussion proceeds from two different aspects of awareness: their understanding on Internet reporting and the perceived benefits of Internet reporting. This is the first and most important question posed to the interviewees during the interview sessions. The objective is mainly to get an overall idea of the interviewees' understanding on the Internet reporting issues. The data is then cross-analysed with the respondent's profile.

All the managers interviewed knew what is Internet reporting. All the respondents agreed:

Internet reporting is just another channel of communication to promote continuous disclosure and it is a way forward.

All the respondents highlighted the importance of having such activities. For example C1, C2 and C7 said:

The company should be transparent, responsible and accountable to shareholders through release of timely company information by the Internet. The reporting must be relevant and include all necessary documents.

Another respondent admitted: 
I think certain size and background of company may be stronger in Internet disclosure, which leads to variation in quality of reporting by the Internet. (C3)

The above data shows the awareness of Internet reporting is quite high among the respondents.

Most of the respondents agreed this technology can reach more potential users and they can access the companies' financial information easily by the Internet. It also enhances the speed of reporting and disclosure can be shortened. Presentation of information is under the companies' full control at any point of time.

In finding some reasoning to why the companies disclose by the Internet, further analysis was done on the respondents' background. Most of the respondent's interviewed were from the Investor Relations Department. For example, respondents from C1, C3, C4, C5, C7 and C8 were managers or top managers holding a post in the Investor Relations Department. The process of preparing public reporting of operating and financial data by the World Wide Web seems to fall under the responsibility of the investor relations department. Of course, to prepare the accounting or financial report, the finance or accounts department is fully responsible. The public reporting documents are then sent to the investor relations to include other investor relation information to be released to investors. For example, respondents clearly stated the process of preparing investor relations materials:

Our company fully complies with all disclosure requirements set by regulators, such as Securities Commission and Bursa Malaysia. (C1 and C7)

Our reporting is based on the basic requirements of the stock exchange, Bursa Malaysia. (C2, C5 and C6)

When setting up a corporate information Web site, the most commonly consulted information source appears to be the competitors' Web sites. It is possible, therefore, for the companies to copy the best features of the innovators for their ongoing improvement on the companies Web sites (C3, C5, C6 and C8). Respondents said:

We refer to the overseas Web sites to get new ideas, especially from those agencies' award winners, as they are more informative, comprehensive and well-designed.

We only compare with the best companies irrespective of its size and where it is located. (C7)

Usually, the decision to make information available in the public domain has already been 
decided by company officers, notably preliminary announcements, quarterly reports and annual reports. According to several interviewees, regulation can put a brake on further developments. For example, to avoid misleading investors, the dissemination of forecast information has to be treated cautiously.

\subsection{Theme Guided Questions: Motivations}

A detailed matrix table of the data was developed based on the simplified coded data identified from the transcripts. The description of the data display is similar to Huberman and Miles (2002) who define display as a compressed, organised information collection that allows conclusion drawing and action. To understand what is happening one needs to refer to the data display (Huberman and Miles, 2002), and to see the patterns, regularities, and the causal relationship. Subsequently, the disclosure theories are used to interpret the finding because the core issues emanating from the finding are encapsulated in the preparers' perspective. The researchers listed the simplified coded motivation first before constructing the matrix table. The motivations identified from the interview data are as follows:

M1 - To be more transparent in communicating company information. They want to ensure the public have good access to company information. It helps investors to invest and convince potential investors the company is a good stock in which to invest.

M2 - Promoting their products and services to create a good brand name in the industry.

M3 - A strong believer of good corporate governance best practices.

M4 - To compete for finance.

M5 - To set a good example for other listed companies to follow.

M6 - To project a good corporate image.

M7 - Wanting to be known by all, and not just an item on the Stock Exchange.

The above information is distilled after several rounds of reiteration. The motivations with the same meaning are grouped into seven (7) core codes. The data is then cross-analysed with the company profile. The matrix table is then developed as shown in Table 1.

To ensure no data is missed out and ensure analysis is completed, the researchers listened to all the respondents' recorded interviews and revisited the transcripts several times. 


\section{Macrothink}

Table 1. Code Matrix Display - Motivation of Internet Reporting

\begin{tabular}{|l|l|l|l|l|l|l|l|l|l|l|l|}
\hline Motivation of Interviewees & C1 & C2 & C3 & C4 & C5 & C6 & C7 & C8 & C9 & C10 & $\begin{array}{c}\text { Total } \\
\text { n=10 }\end{array}$ \\
\hline M1 - To be more transparent & $\sqrt{ }$ & & $\sqrt{ }$ & & $\sqrt{ }$ & $\sqrt{ }$ & $\sqrt{ }$ & $\sqrt{ }$ & $\sqrt{ }$ & $\sqrt{ }$ & 8 \\
\hline $\begin{array}{l}\text { M2 - Promoting their products } \\
\text { and services to create a good } \\
\text { brand name in the industry }\end{array}$ & $\sqrt{ }$ & $\sqrt{ }$ & & & & $\sqrt{ }$ & $\sqrt{ }$ & & & & 4 \\
\hline $\begin{array}{l}\text { M3 - Strong believer of good } \\
\text { corporate governance best } \\
\text { practices }\end{array}$ & & & $\sqrt{ }$ & $\sqrt{ }$ & $\sqrt{ }$ & $\sqrt{ }$ & & & & & 5 \\
\hline M4 - To compete for finance & & & & $\sqrt{ }$ & & & & & $\sqrt{ }$ & & 2 \\
\hline $\begin{array}{l}\text { M5 - To set a good example for } \\
\text { other listed companies to follow }\end{array}$ & & & & $\sqrt{ }$ & & & & $\sqrt{ }$ & & & 2 \\
\hline $\begin{array}{l}\text { M6 - To project a good corporate } \\
\text { image }\end{array}$ & & & & & $\sqrt{ }$ & & & & & 1 \\
\hline $\begin{array}{l}\text { M7 - Wanting to be known by } \\
\text { all, and not just an item on the } \\
\text { Stock Exchange }\end{array}$ & & & & & & & & & $\sqrt{ }$ & $\sqrt{ }$ & 2 \\
\hline
\end{tabular}

$\mathrm{n}=$ number of respondents

\subsection{Theme Guided Questions: Influences}

The researchers asked the respondents the influences of IFR under the themes guided questions. Table 2 shows the results of these questions. All respondents claimed ownership structure influenced IFR, and seven (7) respondents agreed industry members and firm size influenced such reporting practice.

Table 2. Influences of Firms' Characteristics

\begin{tabular}{|l|l|l|l|l|l|l|l|l|l|l|l|}
\hline & C1 & C2 & C3 & C4 & C5 & C6 & C7 & C8 & C9 & C10 & n=10 \\
\hline & $\sqrt{ }$ & $\sqrt{ }$ & $\sqrt{ }$ & $\sqrt{ }$ & $\sqrt{ }$ & $\sqrt{ }$ & & $\sqrt{ }$ & & & 7 \\
\hline Firm size & & $\sqrt{ }$ & $\sqrt{ }$ & & $\sqrt{ }$ & $\sqrt{ }$ & & $\sqrt{ }$ & $\sqrt{ }$ & $\sqrt{ }$ & 7 \\
\hline Financial performance & & $\sqrt{ }$ & & $\sqrt{ }$ & & & & $\sqrt{ }$ & $\sqrt{ }$ & $\sqrt{ }$ & 5 \\
\hline Beta (systematic risk) & & & & & $\sqrt{ }$ & & & & $\sqrt{ }$ & $\sqrt{ }$ & 3 \\
\hline Auditor type (Big 4 or non-Big 4) & & & & & & $\sqrt{ }$ & & & & & 1 \\
\hline Ownership structure & $\sqrt{ }$ & $\sqrt{ }$ & $\sqrt{ }$ & $\sqrt{ }$ & $\sqrt{ }$ & $\sqrt{ }$ & $\sqrt{ }$ & $\sqrt{ }$ & $\sqrt{ }$ & $\sqrt{ }$ & 10 \\
\hline Board governance structure & & $\sqrt{ }$ & & & & $\sqrt{ }$ & & $\sqrt{ }$ & $\sqrt{ }$ & $\sqrt{ }$ & 5 \\
\hline
\end{tabular}

$\mathrm{n}=$ number of respondents

The researchers asked respondents to say to what extent they disagreed or agreed with the influences of ownership and corporate governance mechanism on a Likert-scale of 1 (strongly disagree) to 7 (strongly agree). Responses are summarised and analysed in Tables 3 and 4. 
As shown in Table 3, in total 90\% of the respondents agreed family owned (10); institutional owned (8); government owned (10); foreign owned (9) and director owned (8) influenced the IFR practice. All 10 respondents said the family-controlled firms are not likely to disclose voluntary information above the mandatory requirements because there is a low demand for public disclosure. According to the respondents, larger equity institutional investors will oversee company management and policies because they have the voting power to pressure self-serving management. As for foreign owned firms, because of the geographical separation between management and foreign owners, the demand for disclosure is also greater.

Table 3. Influences of Ownership

\begin{tabular}{|l|l|lll|l|lll|}
\hline \multirow{2}{*}{ Ownership } & \multicolumn{7}{|l|}{ Level of Agreement } \\
\cline { 3 - 9 } & $\mathrm{n}$ & 1 & 2 & 3 & 4 & 5 & 6 & 7 \\
\hline Family owned & 10 & 0 & 0 & 0 & 0 & 1 & 8 & 1 \\
Institutional owned & 10 & 0 & 1 & 0 & 1 & 0 & 6 & 2 \\
Government owned & 10 & 0 & 0 & 0 & 0 & 2 & 6 & 2 \\
Foreign owned & 10 & 0 & 0 & 0 & 1 & 0 & 7 & 2 \\
Director owned & 10 & 0 & 0 & 0 & 2 & 1 & 5 & 2 \\
\hline \multicolumn{7}{|c|}{$1(2 \%)$} & $4(8 \%)$ & $45(90 \%)$ \\
\hline
\end{tabular}

$\mathrm{n}=$ number of responses

Level of agreement on a scale of:

1=strongly disagree $2=$ disagree $3=$ slightly disagree $4=$ neutral $5=$ slightly agree $6=$ =agree 7=strongly agree

The results concerning the influence of corporate governance mechanism on IFR varied widely. This shows respondents were largely unsure about its influence, with $34 \%$ of respondents agreeing the corporate governance mechanism influences IFR and $49 \%$ of the respondents indicating the corporate governance mechanism does not influence IFR. Four (4) respondents said audit committee size was neutral to IFR practice and three (3) respondents had the opinion audit committee meeting frequency was also neutral to IFR practice. Four (4) respondents disagreeing the audit committee financial expert influences IFR, while five (5) respondents agreeing audit committee financial expert influences IFR. 


\section{Macrothink}

Table 4. Influences of Corporate Governance Mechanism

\begin{tabular}{|c|c|c|c|c|c|c|c|c|}
\hline \multirow[b]{2}{*}{ Corporate Governance } & \multirow[b]{2}{*}{$n$} & \multicolumn{7}{|c|}{ Level of Agreement } \\
\hline & & 1 & 2 & 3 & 4 & 5 & 6 & 7 \\
\hline Board size & 10 & 1 & 7 & 1 & 1 & 0 & 0 & 0 \\
\hline Non-executive dir. & 10 & 1 & 2 & 1 & 2 & 2 & 2 & 0 \\
\hline Independent dir. & 10 & 1 & 2 & 1 & 0 & 2 & 3 & 1 \\
\hline CEO Duality & 10 & 1 & 1 & 3 & 2 & 2 & 1 & 0 \\
\hline Director with finance \& acc. & 10 & 1 & 1 & 2 & 1 & 0 & 4 & 1 \\
\hline Family director & 10 & 1 & 2 & 3 & 2 & 0 & 1 & 1 \\
\hline Multiple directorship & 10 & 1 & 2 & 1 & 1 & 0 & 4 & 1 \\
\hline Audit committee size & 10 & 1 & 3 & 1 & 4 & 0 & 1 & 0 \\
\hline AC financial expert & 10 & 1 & 2 & 1 & 1 & 0 & 4 & 1 \\
\hline Board \& AC meeting frequency & 10 & 1 & 2 & 1 & 3 & 0 & 2 & 1 \\
\hline \multicolumn{5}{|c|}{49 (49\%) } & $17(17 \%)$ & \multicolumn{3}{|c|}{34 (34\%) } \\
\hline
\end{tabular}

$\mathrm{n}=$ number of respondents

Level of agreement on a scale of:

$1=$ strongly disagree $2=$ disagree $3=$ slightly disagree $4=$ neutral $5=$ slightly agree $6=$ agree $7=$ strongly agree

\subsection{Applicability of Disclosure Theories}

Several theories, such as positive accounting theories and institutional theory, determined the accounting choice and disclosure.

The interview data reveals the respondents place high regard on the environmental actors as argued by institutional theory. For example, C4 states:

For XBRL implementation, U.S. companies converted data from June 2009 onward. Japan presented their annual report 2008 in XBRL format. Our neighbouring country, Singapore companies incorporated after 1/11/2007 are required to present annual return in XBRL format, 29 Thai companies participate in a pilot project to develop reporting in XBRL. Malaysia companies are not doing it yet. Eventually, we will follow others.

C2's explanation for their reporting format:

We benchmark ourselves against other exchanges such as Australia, New York, Singapore and Hong Kong. We also refer to award winners and foreign companies.

From the institutional perspective, external factors appear to assert the normative and 
coercive pressure to institutionalise C4 and C2. C4 further mentioned the majority of their partners come from overseas companies where the IFR in XBRL format is very significant and common. The above data also confirms C4 and C2 are giving higher priority to the demands of relevant actors. They see the importance of sharing the same feeling towards IFR. To enhance the companies' reputation they chose to adopt this practice to gain greater legitimacy. Clearly, C4's incentive to adopt IFR in XBRL format appears to draw on this notion.

Political costs theory can explain the relationship between industry and disclosure. Indeed, according to Watts and Zimmerman (1990), industry member being related to size is associated with political costs. Industry type may also change the proprietary costs. Signalling theory argues companies in the same industry are more likely to have the same disclosure level, to gain positive market appreciation. According to respondent C1:

Our company takes into account what the competitors are doing for competitive position and assessment.

The relationship between size and disclosure can be explained from several theoretical arguments. Watts and Zimmerman (1990) argue higher political costs in larger companies resulted in them having a higher disclosure level to reduce political costs and improve market confidence. In addition, larger companies are likely to have more advanced information systems, therefore, additional disclosure will supposedly cost less in comparison with the smaller companies. At the same time, as company size increases, the proprietary costs for competitive advantages of additional disclosure are smaller (Verrecchia, 1983). Respondents C2 and C3 said:

Bigger companies may have better data presentation to convince the company is doing well, to gain confidence from public and investors. They have greater resources to report by the Internet (C2).

Bigger firms tend to have their own Web site. Smaller companies may not have a dedicated investor relation team to take care of such function, because they may not have sufficient resources and budget. There are some smaller companies cannot even differentiate between Investor Relations, Corporate Communication and Public Relations (C3).

The greater proportion of equity capital structure, the higher the level of information expected by shareholders, thus, incurring higher monitoring costs. The agency cost reduction has the same argument. However, the same problem exists regarding inside versus outside equity. When there is a larger equity from inside, additional disclosure becomes unimportant since the internal owners have greater access to company information. Respondent C1 stressed: 
Family owned firms require a lower level of disclosure. As for institutional owned, they demand a higher level of disclosure, otherwise, the institutional investors could dispose of their investments if they are unhappy with the company's disclosure!

Another respondent C2 argued:

Institutional owned tends to be more transparent to attract investment and gain confidence from investors. Family/director owned tends to be more secretive, i.e. they may "hide" information from the public to protect cronies such as related-party transactions.

\subsection{Issues of Internet Reporting}

The researchers asked the respondents for any issues pertaining to Internet reporting. A number of issues have been sub-grouped for easy comparison.

\subsubsection{Regulation of reporting}

Although there was a general agreement IFR will at least be allowed, there were disagreement on the extent and necessity of regulations. Some respondents adopted a dynamic perspective, while others expressed a static view. Because the Internet represents a radical change in the commercial process, six (6) respondents expected the need for new regulations. However, all thought it is important whatever controls are developed and used, they should not hinder the freedom of a company's management to present useful information on the Internet. Others believed no regulation would be necessary, because they assume a company will only present audited or reviewed information on the Web page. Furthermore, the exact reproduction of the hard copy on the Web will give rise to legal issues.

\subsubsection{Security of the Web site}

Web site security is the main concern of all the respondents. It may not be easy to control the access of the Web site or its underlying database. Needless to say, hackers and hostile intruders can and do find loopholes in the company's security net, they may change the data without the company's knowledge. For example, C1, C2, C5 and C6 said:

There is a potential risk by irresponsible hackers to alter the content of information on company Web pages.

Even if the security is adequately provided, the chances of fraudulent information being communicated through similar technologies and chat rooms still exist and the company can be adversely affected by such information. 


\subsubsection{Timeliness of Reporting}

The Internet improves the availability of financial information to company users, it helps to increase the frequency of reporting from annually or quarterly to monthly, weekly, daily or even almost instant annual reports. The Internet facility is a pre-requisite in order to achieve a high frequency of reporting. For example, after the company released the announcements, such information should be provided instantly on the company web page else it will lose value fast, as the delivery to users is too late relative to the duration it covers. A major change in most accounting systems is required, because more frequent reporting for events, such as updates of estimates, judgements and market prices would need a real-time entry. The respondents highlighted:

My concern is we need to do a lot of regular updates to ensure timely information is posted on our Web site (C3).

Continuous disclosure requires constant efforts to update and change the Web's information (C5).

Omission of material transactions caused by late release by authorised personnel may occur (C6).

\subsection{4 eXtensible Business Reporting Language (XBRL)}

XBRL International promulgates a computer language using an emerging technology. It is a global consortium of over 200 technology, accounting and financial services. Within XBRL, a predefined and unique data tag is assigned to each piece of financial data. These data tags act as the barcodes to identify the content and structure of information. The XBRL proponents claim to have the ability to affect users' financial information acquisition and processing, as their decisions and judgements are based on its output.

The main facility offered by XBRL is its ability to acquire and integrate the financial information from a company's financial statement and code it. For users who are using this software application, the coded financial statements will facilitate the extraction process, and simultaneously show all identically coded information from annual reports and footnotes (Hodge, Kennedy and Maines, 2004). Many developed countries are adopting XBRL coded financial statements in view of the above benefit. These countries include Canada, Germany, Hong Kong, Japan, Singapore, the U.K. and U.S., as well as the IASB (XBRL News, 2002). However, according to C4:

Since 2008, our neighbouring countries such as Thailand and Singapore began to instruct their listed companies to use XBRL coded financial statement on the Internet. Many listed companies in Malaysia are yet to adopt IFR on their corporate Web sites, some of them are struggling to set 
up a company Web site!

According to Dull et al. (2003), through the professional bodies, software companies and accounting firms' support, XBRL is becoming an emerging financial reporting standard. Malaysian regulatory agencies and/or the stock exchange should seriously consider encouraging the listed companies to adopt XBRL in view of the above benefits and adoption by the neighbouring countries.

\subsubsection{Internet Reporting is “Individual Driven”}

Company personnel to varying degrees and seniority can carry out the Investor relations function, but involvement by directors is generally considered to be desirable in the managing and executing of the activities.

According to the respondents, the majority of the board of directors clearly accepted the principal responsibilities of communication. The influence of one senior member may affect the company decision to set up or improve an existing Web site. Usually, a senior executive is responsible for the Web site project, together with substantial involvement from the directors. C1, C8, C9 and C10 stressed,

The Board is the key driver to greater transparency beyond the mandatory disclosure compliance.

The interview results suggest it is generally a high level decision with close participation from one or more directors to improve greater transparency of information.

\section{Conclusion}

This paper bridges the gap by interviewing ten senior managers to seek their views and opinions concerning influences of corporate governance and ownership structures on IFR. Relatively, all the respondents interviewed provided good cooperation and the insights gained from the interviews are very valuable for this study. It provides a clear picture concerning the manager's perception, awareness and understanding on the concept of IFR. All the managers interviewed knew what is Internet reporting. Most of the respondents agreed the Internet offers easy access to company financial information. More potential users can be reached through this technology. Information publication time is under the absolute control of the companies. Therefore, Internet disclosure enhances disclosure speed.

The main motivation as to why companies disclose information by the Internet is identified from the interview data. Among the three main motivations are: first, companies want to be more transparent in disseminating company information. They want to ensure the public have good access to company information. The information helps investors to make investment decisions and persuade prospective investors to invest in the firm. Second, the companies use the Internet to promote their products and services to create a good brand name in the industry. Lastly, these companies that used Internet to disseminate information are a strong believer of good corporate governance best practices in promoting greater transparency. 
This study identifies the emergent pattern and discusses the influences of ownership structures and corporate governance mechanisms on IFR. $90 \%$ of the respondents claimed ownership structure influenced IFR, and $70 \%$ of the respondents agreed industry members and firm size influenced such reporting practice. As for corporate governance mechanisms, $34 \%$ of the respondents agreed corporate governance influenced IFR. This study identifies issues concerning Web-based business reporting from the preparers' perspective. Among the more significant issues are the security of the Web site, timeliness of reporting and adoption of XBRL.

The sample size of this study is small and it may not represent the views of other preparers from all listed companies. Extending to bigger sample size could carry out in future research. It would also be useful to adopt a longitudinal approach, which can help to shed further light on the evolving process of Internet-based disclosure practices and its adoption.

\section{References}

Abdelsalam O.H., Bryant S.M. \& Street D.L. (2007). An Examination of the Comprehensiveness of Corporate Internet Reporting Provided by London-Listed Companies. Journal of International Accounting Research, 6(2), 1-33. http://dx.doi.org/10.2308/jiar.2007.6.2.1

Abdul Hamid F.Z., Salleh M.S. M \& Saad S. (2004). The Extend of Investor Relations Information in the Malaysian Companies Web Sites. Working Paper Series No. 7/2004, Universiti Utara Malaysia.

Ali Khan M.N.A. \& Ismail N.A. (2009). Internet Financial Reporting in Malaysia: Factors, Pros and Cons. Accountants Today, 22(2), 28-31.

Beattie V. \& Pratt K. (2003). Issues Concerning Web-based Business Reporting: An Analysis of the Views of Interested Parties. The British Accounting Review, 35, 155-187. http://dx.doi.org/10.1016/S0890-8389(03)00016-7

Bonson E. \& Escobar T. (2006). Digital Reporting in Eastern Europe: An Empirical Study. International Journal of Accounting Information Systems, 7, 299-318. http://dx.doi.org/10.1016/j.accinf.2006.09.001

Cooper R.D. \& Schindler P.S. (2006). Business Research Methods (9th Edition). NY: McGraw-Hill.

Debreceny R, Gray G.L. \& Rahman A. (2002). The Determinants of Internet Financial Reporting. Journal of Accounting and Public Policy, 21, 371-394. http://dx.doi.org/10.1016/S0278-4254(02)00067-4

Debreceny R. \& Rahman A. (2005). Firm-Specific Determinants of Continuous Corporate Disclosures. The International Journal of Accounting, 40, 249-278. http://dx.doi.org/10.1016/j.intacc.2005.06.002

Dull R.B., Graham A.W. \& Baldwin A.A. (2003). Web-Based Financial Statements: Hypertexts Links to Footnotes and Their Effect on Decisions. International Journal of 
Accounting

Information

Systems,

4 ,

185-203.

http://dx.doi.org/10.1016/S1467-0895(03)00009-5

Ettredge M., Richardson V.J. \& Scholz S. (2002). Dissemination of Information for Investors at Corporate Web Sites. Journal of Accounting and Public Policy, 21, 357-369. http://dx.doi.org/10.1016/S0278-4254(02)00066-2

Gan C.W. \& Susela D. S. (2006). Internet Financial Reporting in Malaysia: An Investigation of Firm Characteristics. Accounting Theory \& Practice: A Malaysian Perspective (pp.365-373). Malaysia: Pearson Prentice Hall.

Hassan S., Jaffar N., Johl S.K. and Zain M.N.M. (1999). Financial Reporting on the Internet by Malaysian Companies: Perceptions and Practices. Asia-Pacific Journal of Accounting, 6(2), 299-319.

Hodge F.D., Kennedy J.J. \& Maines L.A. (2004). Does Search-Facilitating Technology Improves the Transparency of Financial Reporting? The Accounting Review, 79(3), 687-703. http://dx.doi.org/10.2308/accr.2004.79.3.687

Huberman A.M. \& Miles M.B. (2002). The Qualitative Researcher's Companion. Thousand Oaks, CA: Sage Publications.

Ismail N. A. and Tayib M. (2000). Financial Reporting Disclosure on the Internet by Malaysian Public Listed Companies. National Accountants (Nov/Dec), 28-33.

Jamaliah T, Radiah O. \& Noraini M.N. (2001). Internet Financial Reporting by Malaysian Banks and Financial Institutions. Paper presented at AAAA Conference, Penang.

Jones M.J. \& Xiao J.Z. (2004). Financial Reporting on the Internet by 2010: A Consensus View. Accounting Forum, 28, 237-263. http://dx.doi.org/10.1016/j.accfor.2004.07.002

Kelton A.S. \& Yang Y. (2008). The Impact of Corporate Governance on Internet Financial Reporting. Journal of Accounting \& Public Policy, 27, 62-87. http://dx.doi.org/10.1016/j.jaccpubpol.2007.11.001

Lymer A., R. Debreceny, G. Gray and A. Rahman (1999). Business Reporting on the Internet. London: International Accounting Standard Committee, September.

Marston C. \& Polei A. (2004). Corporate Reporting on the Internet by German Companies. International Journal of Accounting Information Systems, 5, 285-311. http://dx.doi.org/10.1016/j.accinf.2004.02.009

Mohamad R., Mohamad A. \& Mohamad M. (2003). Internet Financial Reporting in Malaysia: A Survey of Contents and Presentations. Working Paper Series No. 8/2003, Universiti Utara Malaysia.

Nik Salleh N.M.Z. and A Mohd (2000). Web-based Financial Reporting in Malaysia. In Seminar on Accounting and Information Technology. Universiti Utara Malaysia, November.

Patten D.M. (2002). Give or Take on the Internet: An Examination of the Disclosure Practices 
of Insurance Firm Web Innovators. Journal of Business Ethics, 36, 247-259. http://dx.doi.org/10.1023/A:1014009229437

Punch K.F. (2005). Developing Effective Research Proposal. London: Sage Publications.

Saunders M., Lewis P. \& Thornhill A. (2009). Research Methods for Business Students (5th Edition). U.K.: Pearson Education Ltd.

Verrecchia R. (1983). Discretionary Disclosure. Journal of Accounting \& Economics 5(3), 179-194. http://dx.doi.org/10.1016/0165-4101(83)90011-3

Watts R.L. \& Zimmerman J.L. (1990). Positive Accounting Theory: A Ten Year Perspective. Accounting Review 65(1), 131-156.

XBRL News. (2002). XBRL Standard for Capital Markets Enjoys Growing International Adoption. $\quad$ Retrieved October 24th, 2009, from http://xml.coverpages.org/ni2002-03-05-a.html.

Xiao Z., Jones M.J. and Lymer A. (2002). Immediate Trends in Internet Reporting. The European Accounting Review, 11(2), 245-275. http://dx.doi.org/10.1080/09638180020017087a

Xiao J.Z., Yang H. \& Chow C.W. (2004). The Determinants and Characteristics of Voluntary Internet-Based Disclosures by Listed Chinese Companies. Journal of Accounting \& Public Policy, 23, 191-225. http://dx.doi.org/10.1016/j.jaccpubpol.2004.04.002

\section{Appendix 1 Questionnaire}

\section{INTERVIEW ON INTERNET REPORTING (IR):}

The interview will be divided into 2 types of questions:

$\checkmark \quad$ Open-ended questions;

$\checkmark \quad$ Theme guided questions.

All these questions are related to IR. Let me briefly define what IR is.

IR means reporting corporation information via the company's Web site. Currently IR is voluntary in nature with no specific regulations. Therefore, there is a disparity of IR practices among companies. List of questions are as follows:

Open-ended questions

1. What is your perception on Internet reporting?

2. Why does your company disclose information on company Web site?

3. What motivate you to disclose?

4. How do you come out with the reporting format?

5. Any other issues pertaining to Internet reporting? 


\section{Themes guided questions:}

1. Do you think statutory body/accounting standard body/securities regulator should regulate company Internet reporting? Why? How?

2. Do you think industry members have any influence on company Internet reporting? Why? How?

3. Do you think firm size has any influence on your company Internet reporting? Why? How?

4. Do you think financial performance (profitability) has any influence your company Internet reporting? Why? How?

5. Do you think beta (systematic risk) has any influence your company Internet reporting? Why? How?

6. Do you think auditor (Big-4 or non Big-4) has any influence your company Internet reporting? Why? How?

7. Do you think ownership structure has any influence on your company Internet reporting? Why? How?

Think in term of ownership structure's influence on Internet reporting. Please put the most appropriate response number on the side of each ownership structure, using the scale below

$\begin{array}{lllllll}\text { Strongly } & \text { Disagree } & \begin{array}{l}\text { Slightly } \\ \text { Disagree }\end{array} & \text { Neutral } & \text { Slightly } & \text { Agree } & \text { Strongly } \\ \text { Disagree } & 2 & 4 & \text { Agree } & 6 & \text { Agree } \\ 1 & & 3 & & 5 & & 7\end{array}$

Family owned

Institutional owned

Government owned

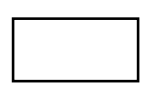

Foreign owned

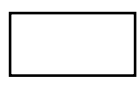

Director owned

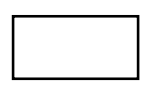




\section{Macrothink}

Think in term of board governance structure's influence on Internet reporting. Please put the most appropriate response number on the side of each board governance structure, using the scale below:

$\begin{array}{lllllll}\text { Strongly } & \text { Disagree } & \text { Slightly } & \text { Neutral } & \text { Slightly } & \text { Agree } & \text { Strongly } \\ \text { Disagree } & 2 & \text { Disagree } & 4 & \text { Agree } & 6 & \text { Agree } \\ 1 & & 3 & & 5 & & 7\end{array}$

Board size

Non-executive director

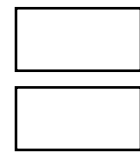

Independent director

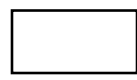

CEO duality

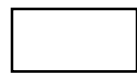

Director with finance \& accounting qualification

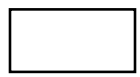

Family member of founder on board

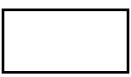

Director sits in more than 1 board

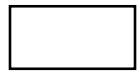

Size of audit committee

Audit committee with finance \& accounting qualification

Board and Audit committee meeting frequency

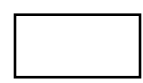

\section{Personal Details:}

Position in the company:

No of years at the Managerial level:

Area of expertise and experience:

Appendix 2 Profile of Respondents 
Respondent C1 is an accountant by profession and was attached to the accounting and auditing industry for 8 years before joining the company in 1988. He was initially attached to the Finance Division in the Head Office, and transferred to the group company in Hong Kong in 1990. He returned to Head Office in 1994 and was appointed Senior General Manager in 2001 and Chief Operating Officer in 2008. His portfolio includes supervision of the company’s Banking Operations, Finance, Property and Information Technology Divisions.

Respondent C2 has 22 years in the finance and accounting profession. She is involved in tax planning, auditing, financial management and project management. She holds a Master of Business Administration (MBA) from the University of Lincoln (U.K.).

Respondent C3 is the Head of Investor, Finance. She has more than 14 years of managerial experience. Her responsibilities in the company include public release to Bursa, placing relevant information on the company Web site, and meeting with analysts, fund manager and shareholders. She also holds analyst teleconferences and media conferences, and attends road shows to update investors on the company's outlook.

Respondent C4 is the Chief Executive Officer of the company. He has more than 10 years of experience in investor relations and corporate finance.

Respondent C5 is the Investor Relations Manager of the company. He has more than 5 years of experience in finance and investor relations.

Respondent C6 is the independent director of the company for 9 years. He has more than 15 years at the managerial level. His area of expertise and experience includes accounting, finance and corporate management. He holds Master of Business Administration (MBA) from the University of Malaya. He is also a member of the Malaysian Institute of Accountants.

Respondent C7 is the Head of Group Investor Relations. He has more than 10 years at the managerial level. His area of expertise and experience includes accounting, auditing, finance, strategic planning, performance management and investor relations.

Respondent C8 is the Head, Investor Relations from CEO's office. She has 16 years at the managerial level. Her portfolio includes investor relations.

Respondent C9 is the Senior Manager of Corporate Planning. He has 6 to 7 years at the managerial level. His portfolio includes accounting, corporate finance and treasury.

Respondent C10 is the Assistant Manager of Corporate Planning. He has 5 years at the managerial level. His area of expertise and experience includes audit, finance and business development. 
Details of the Respondents

\begin{tabular}{|c|c|c|c|}
\hline Company & Industry & Designation & Expertise \& Experience \\
\hline $\mathrm{C} 1$ & Finance & Chief Operating Officer & $\begin{array}{l}\text { Investor relations head, accountant, } \\
\text { past senior general manager }\end{array}$ \\
\hline C2 & Construction/property & Finance Manager & $\begin{array}{l}\text { Tax, audit, group accounts \& business } \\
\text { plan }\end{array}$ \\
\hline $\mathrm{C} 3$ & Trading/Services & $\begin{array}{l}\text { Head of Investor } \\
\text { Relations }\end{array}$ & $\begin{array}{l}\text { Internet-based corporate reporting, } \\
\text { liaise with investors }\end{array}$ \\
\hline $\mathrm{C} 4$ & Finance & Chief Executive Officer & Corporate finance, investor relations \\
\hline C5 & Construction/property & $\begin{array}{l}\text { Investor } \quad \text { Relations } \\
\text { Manager }\end{array}$ & Finance \& investor relations \\
\hline C6 & Plantation & Independent director & $\begin{array}{l}\text { Accounting, finance \& corporate } \\
\text { management }\end{array}$ \\
\hline C7 & Finance & $\begin{array}{l}\text { Head Group Investor } \\
\text { Relations }\end{array}$ & $\begin{array}{l}\text { Accounting, auditing, finance, } \\
\text { strategic planning, performance } \\
\text { management and investor relations }\end{array}$ \\
\hline $\mathrm{C} 8$ & Finance & $\begin{array}{l}\text { Head of Investor } \\
\text { Relations from } \text { CEO’s } \\
\text { office }\end{array}$ & Investor Relations \\
\hline C9 & Plantation & $\begin{array}{l}\text { Corporate Planning } \\
\text { Senior Manager }\end{array}$ & $\begin{array}{l}\text { Accounting, corporate finance and } \\
\text { treasury }\end{array}$ \\
\hline C10 & Plantation & $\begin{array}{l}\text { Assistant Manager } \\
\text { Corporate Planning }\end{array}$ & $\begin{array}{l}\text { Audit, finance and business } \\
\text { development }\end{array}$ \\
\hline
\end{tabular}

